\title{
New free-living bryozoans from the northwest European Chalk
}

\author{
ECKART HÅKANSSON \& EHRHARD VOIGT
}

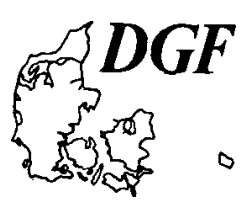

\begin{abstract}
Håkansson, E. \& Voigt, E.: New free-living bryozoans from the northwest European Chalk. Bulletin of the Geological Society of Denmark, vol. 42, pp. 187-207. Copenhagen 199602-01. https://doi.org/10.37570/bgsd-1995-42-15
\end{abstract}

\begin{abstract}
Twelve new species of free-living cheilostome bryozoans are described from the white chalk of Denmark and northern Germany: Lunulites pseudocretacea, L. microstoma, $L$. vespertilio, $L$. conulus, $L$. patens, $L$. immensa, $L$. foveolata, Pavolunulites parva, $P$. schmidi, $P$. insolita, $P$. moenensis, $P$. danica. Eleven species are restricted to the Maastrichtian, while a single species also range down into Upper Campanian strata. The systematic status of the genera Lunulites and Pavolunulites in the Cretaceous is briefly discussed.
\end{abstract}

Eckart Håkansson, Geological Institute, University of Copenhagen, Øster Voldgade 10, DK-1350 Copenhagen K, Denmark. Ehrhard Voigt, Geologisch-Paläontologisches Institut, Universität Hamburg, Bundesstrasse 55, D-20146 Hamburg, Germany. 27th September 1995.

\section{Introduction}

Free-living, lunulitiform bryozoan colonies are conspicuous elements in many soft bottom communities from the Late Cretaceous onwards. Within the anascan cheilostomes pronounced diversity peaks are associated with the Neogene-Recent faunas of the Australian region, the Paleogene faunas of the North American Gulf and Atlantic coastal plains, and the Maastrichtian faunas in northwest Europe. Thus close to 100 lunulitiform species are presently recognised just from the Maastrichtian White Chalk in Denmark and North Germany; here single samples $(c .5 \mathrm{~kg}$ ) have been found to contain as many as 35 free-living bryozoan species.

Free-living, lunulitiform anascans in their typical form are unilamellar disc- or cup-shaped, commonly with a thickened basal wall; the colonies include a specific proportion of heteromorph zooids (vibraculae) with long, bristle-shaped operculae (setae). Depending on the character of the sediment this type of colony may either lie loose on the sediment surface supported by stiff marginal setae or - in sandy environments in particular - occupy a more or less submersed position in the sediment; by means of coordinated setal activity some species are capable of moving about on or in the sediment (Cook \& Chimonides 1978, Håkansson \& Winston 1985).

The Maastrichtian chalk faunas include a significant number of bryozoan species assumed to be free-living although they do not possess vibraculae (Håkansson 1975, Håkansson \& Voigt 1995); whether such freeliving forms should be classified as lunulitiform is de- batable, but as stressed by Håkansson \&Winston (1985) the inclusion of rooted colonies in this ecologically founded category is definitely not recommendable.

Several cheilostome families include free-living forms in which a varying degree of convergence can be detected. Three anscan families with a significant fossil record are almost exclusively lunulitiform (Lunulitidae Lagaaij, 1952, Selenariidae Harmer, 1926, and Cupuladriidae Lagaaij, 1952) and thus share a remarkably long list of advanced colony characters, including basal coeloms and vibracular structure. However, the present systematic understanding of these families is far from satisfactory.

While the Cupuladriidae and the Selenariidae are known only from the Paleogene onwards, the Lunulitidae were probably established in the Coniacian, with pronounced diversification taking place already in the latest Cretaceous. In a series of papers Cook and coworkers (e.g. Cook \& Chimonides 1986) have attempted to clarify the systematic position of the diverse Neogene-Recent faunas from Australia and New Zealand. However, the even more fundamental investigation of the phylogenetic relationships within the ancestral Cretaceous stock is still wanting. In this paper we document a first series of new species from the Danish and German White Chalk to preceed more thorough discussions of these relationships.

In contrast to most other Cretaceous bryozoans the free-living forms are commonly preserved as entire, unbroken colonies. This reflects both their fairly robust construction and their limited, in many cases pos- 


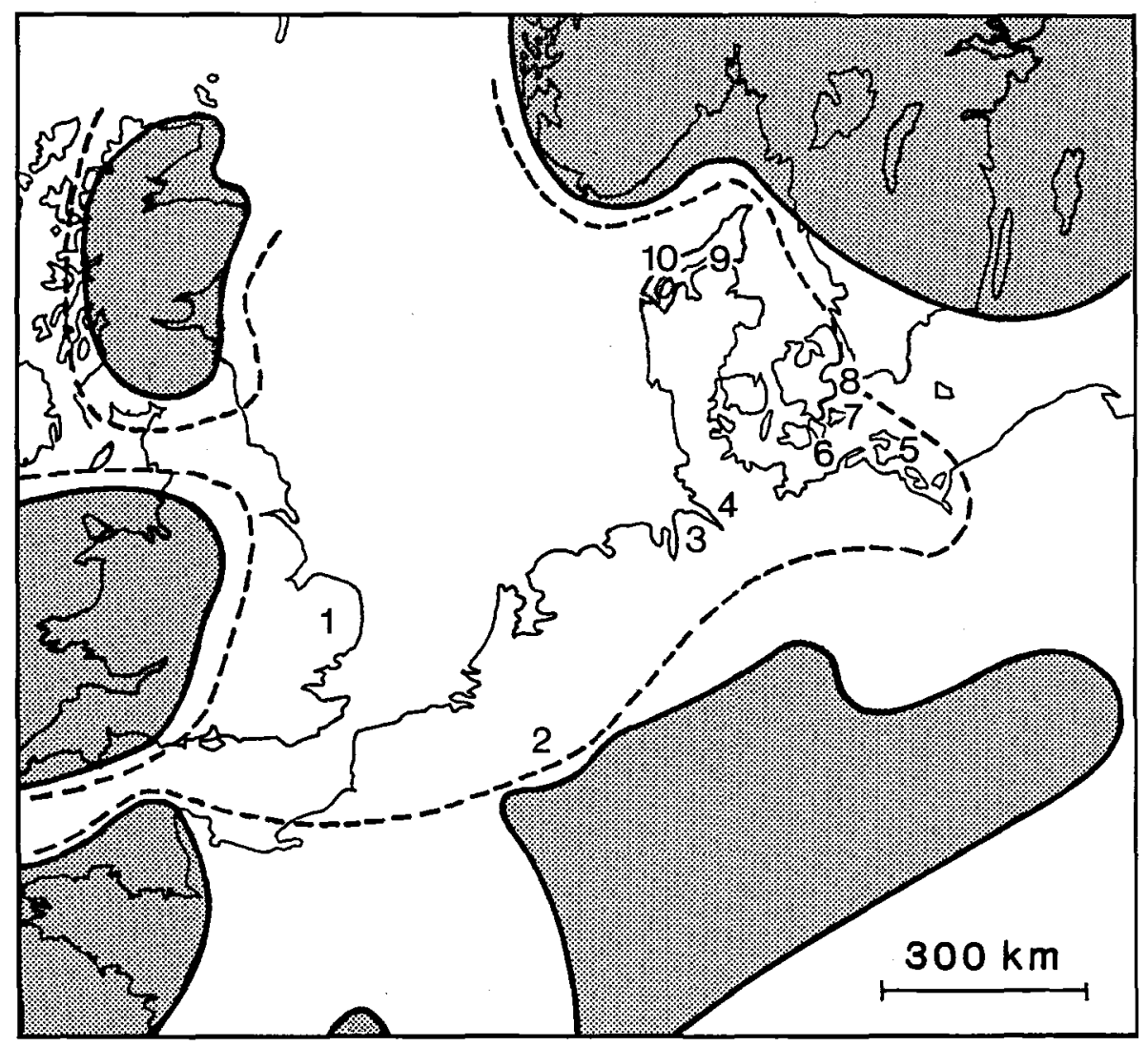

Fig. 1. Maastrichtian paleogeography of the North Sea region; approximate position of localities included in this paper indicated by the numbers 1 to 10. 1: Trimingham, West Runton; 2: Hallembaye, Eben Emael, St. Pietersberg, Geultal; 3: Hemmoor, Basbeck; 4: Lägerdorf; 5: Rügen; 6: Falster, Hasselø, Gjedser Odde, Gjedser Fyr; 7: Hvide Klint, Møns Klint (Hvidskud, St. Taler, Ll. Taler, Jydelejet); 8: Stevns Klint, Karlstrup, Kongsted; 9: Aalborg (Rørdal, "Danmark", "Norden", Nr. Uttrup), Smidie, Gudumholm, Gudumlund, Skovstrup, Nr. Flødal, Ellidshøj, Lundergård, Fjerritslev; 10: Kjølby Gård, Nyvang Gård, Erslev. (Modified from Håkansson et al. 1974)

sibly specific colony size. As a result the budding pattern of the ancestral part of the colony is commonly preserved, to provide an additional, valuable taxonomic tool. It is our experience that zooidal shape and dimensions among the 'lunulite' bryozoans in the Cretaceous are less variable than in other cheilostome bryozoan groups from the same environment. However, this morphological stability is to a varying extent masked by positional differences among zooids of comparable astogenetic age. Since, furthermore, many forms possess a proportionally very extensive zone of astogenetic change (Boardman, Cheetham \& Cook 1970), it follows that zooidal quantitative properties in the free-living bryozoans may vary not only according to the position within the budding pattern, but also to the astogenetic stage. Hence, in extreme cases, no two zooids in a colony are exactly similar although the variation, when comparing zooids in corresponding positions, is indeed very moderate (see Pavolunulites insolita n. sp., Figs 10A-C).
As a result of these particular morphological properties morphometric measurements as traditionally performed in bryozoan studies are of little relevance unless carried out zooid by zooid. Nonetheless, since the free-living colonies are usually more or less complete, straight forward size diffrences still provide a viable background for species separation, provided these differences are consistent and pronounced. Thus, in the lack of specific measurements, we have attempted to facilitate the identification of the new species by standardazing the magnifications in the illustrations, allowing species separation by direct comparison to these illustrations, with carefull consideration of the scale as illucidated by the following species complexes: L. pseudocretacea (Fig. 3D)/L. mi-crostoma (Fig. 4B) and L. immensa (Fig. 7C)/P. schmidi (Fig. 9G)/P. parva (Fig. 9A). 


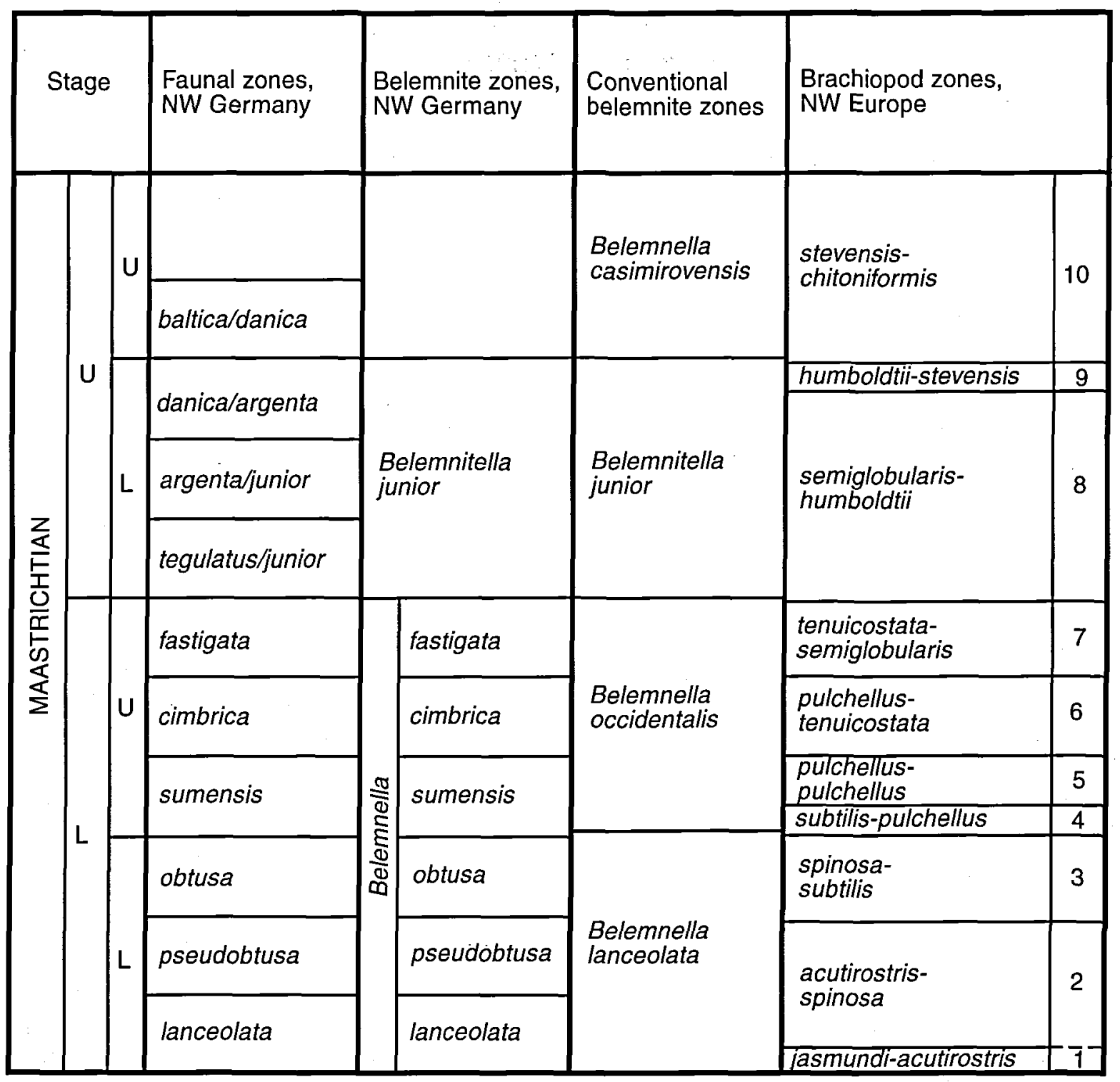

Fig. 2. Belemnite and brachiopod stratigraphy of the Maastrichtian White Chalk of north-west Europe prepared by Dr W. K. Christensen.

\section{Chalk}

Pelagic sediments usually referred to as 'Chalk' or 'White Chalk' constitute one of the most characteristic Upper Cretaceous sediment types across northern Europe. Thus, in Late Campanian and Maastrichtian deposition chalk was totally dominant in the North Sea Basin and surrounding areas of the fairly shallow water shelf sea occupying large parts of Europe in association with major transgressional maxima (Fig. 1).

Maastrichtian chalk is a near $100 \%$ pure biogenic limestone with an overwhelming dominance of coccoliths, and only locally does it contain a notable propor- tion of benthic organisms (Håkansson, Bromley \& Perch-Nielsen 1974). The benthic communities of the Maastrichtian chalk are rather peculiar; while the benthic density is generally very low, the diversity of benthic metazoan species is rather extreme, and it is a noteworthy fact that, in spite of the very fine-grained nature of the chalk, these benthic communities are totally dominated by small suspension-feeders. Bryozoans is by far the most diverse group, exceeding 500 species (Håkansson \& Thomsen 1979), but also brachiopods and bivalves reached unusually high diversities in this environment (Surlyk 1972, Johansen 1988, Heinberg 1979, 1989). 
The Maastrichtian chalk is present in the subsurface virtually all across the North Sea Basin, with local thickness exceeding $700 \mathrm{~m}$ in extreme cases. Exposures are limited however, and each locality rarely represents more than a mere fraction of the total succession. In contrast to the deeply buried chalk in the North Sea, the chalk has suffered very mild diagenesis in most of the present on-shore areas; most localities therefore provide well preserved, easily obtainable benthic assemblages which, by and large, have suffered virtually no transport. On this background a very detailed, essentially basin wide stratigraphic zonation has been established based on brachiopods (Fig. 2; Surlyk 1970, 1984).

\section{Systematic paleontology}

\section{Lunulites and Pavolunulites}

In their broad sense the two genera Lunulites Lamarck, 1816 and Pavolunulites, d'Orbigny, 1852 may account for virtually all Cretaceous members of the Lunulitidae simply according to the budding pattern; Lunulites includes circular, radially budded forms, whereas the fanshaped forms with a marginal ancestrula are classified as Pavolunulites. However, it is already evident that a thorough revision of this diverse group will inevitably result in a much more complex systematic situation. Thus, as an example, the intermediate astogeny exhibited by such species as $L$. beisseli Marsson, $L$. foveolata n.sp., and P. schmidi n.sp. clearly delimit a taxonomic entity, which warrants the formal introduction of a new genus-category name (Håkansson 1974 and unpublished).

The genus Pavolunulites d'Orbigny has a very limited occurrence in post-Cretaceous strata, and very few authors have in fact recognised the existence of this genus. Thus, Bassler (1935), in his Fossilium Catalogus, listed Pavolunulites (together with Lunulites) as a synonym of Reptolunulites d'Orbigny. This practice had few followers (Buge 1946, 1952), and, eventually, in the Treatise Volume, Bassler (1953) arrived at the conclusion that Pavolunulites (a.o. together with Reptolunulites) was a synonym of Lunulites Lamarck. None of these taxonomic exercises were accompanied by any argumentation.

The specimens included in this investigation originate primarily from three sources: a) the very extensive collection of Upper Cretaceous bryozoans contained in the Voigt Collection, University of Hamburg, b) the systematic investigation of the faunas of the Danish Maastrichtian white chalk carried out at the Geological Institute, University of Copenhagen, and c) the systematic investigation of the faunas of the Maastrichtian white chalk at Hemmoor instigated by the Bundesamt für Bodenforschung, Hannover. Type and other illus- trated specimens are stored in the Voigt Collection (under their photo-catalogue number) and the Geological Museum, University of Copenhagen (prefix MGUH).

\section{Lunulites pseudocretacea $\mathrm{n} . \mathrm{sp}$.}

Figs 3A-E

1865 Lunulites cretacea, Beissel, Pl. 3, figs 31-33

1887 Lunulites cretacea, Marsson, Pl. 7, fig. 12

1930 Lunulites cretacea, Voigt, Pl. 19, fig. 18 (non fig. 17)

1972 Lunulites sp., Surlyk, Pl.IV, fig. f

Holotype: MGUH 23088 (Figs 3C-E); Late Maastrichtian (brachiopod zone 9, Ellidshøj).

Material: Upper Campanian chalk: Germany (Lägerdorf, Lüneburg) and Great Britain (W. Runton); Lower Maastrichtian chalk: Denmark (Hvide Klint, Kongsted, Falster, Hvidskud), Germany (Lüneburg, Rügen, Fridrichsberg bei Aachen, Hemmoor), and Great Britain (Trimingham); Upper Maastrichtian chalk: Denmark (Rørdal, "Danmark", Skovstrup, Nr. Flødal, Ellidsh øj, Erslev, Kjølby Gård), Germany (Hemmoor, plus drift), and Belgium (Hallembaye).

Description: Colony circular, in young stages almost flat, later more or less arched with a shallow, concave basal side; composed of rather regular radial rows of autozooids alternating with less regular, discontinuous rows of vibracula. Ancestrula larger than the surrounding autozooids and of somewhat different shape; surrounded by six autozooids and two disto-lateral vibracula. Basal wall with moderate secondary thickening and typically totally calcitic, with a rather uneven surface crossed by irregular, radial furrows corresponding to lateral walls of autozooidal budding rows; vibracular rows not visible on the basal side.

Autozooids slightly elongate rectangular to almost quadratic; cryptocyst flat to slightly concave, bound by a coarsely granulated, flat mural rim; opesia rounded semielliptical to almost quadratic, typically somewhat longer than wide; very seldom opesiae are closed by a cryptocystal lamina.

Vibracula slightly asymmetrical, elongate and tapering distally; with a small oval opesium in the proximal half, surrounded by a narrow cryptocyst; a pair of small condyles developed distal to the opesia.

Ovicells slightly arched, recognisable mostly on the considerably larger, rounded triangular opesia of brooding zooids.

Remarks: This species has previously been recorded under the name Lunulites cretacea Defrance. However, Defrance (1823) gave no illustrations of his material (originating from Néhou, Contentin and St. Pietersberg, Maastricht), and since several Lunulites species occur 

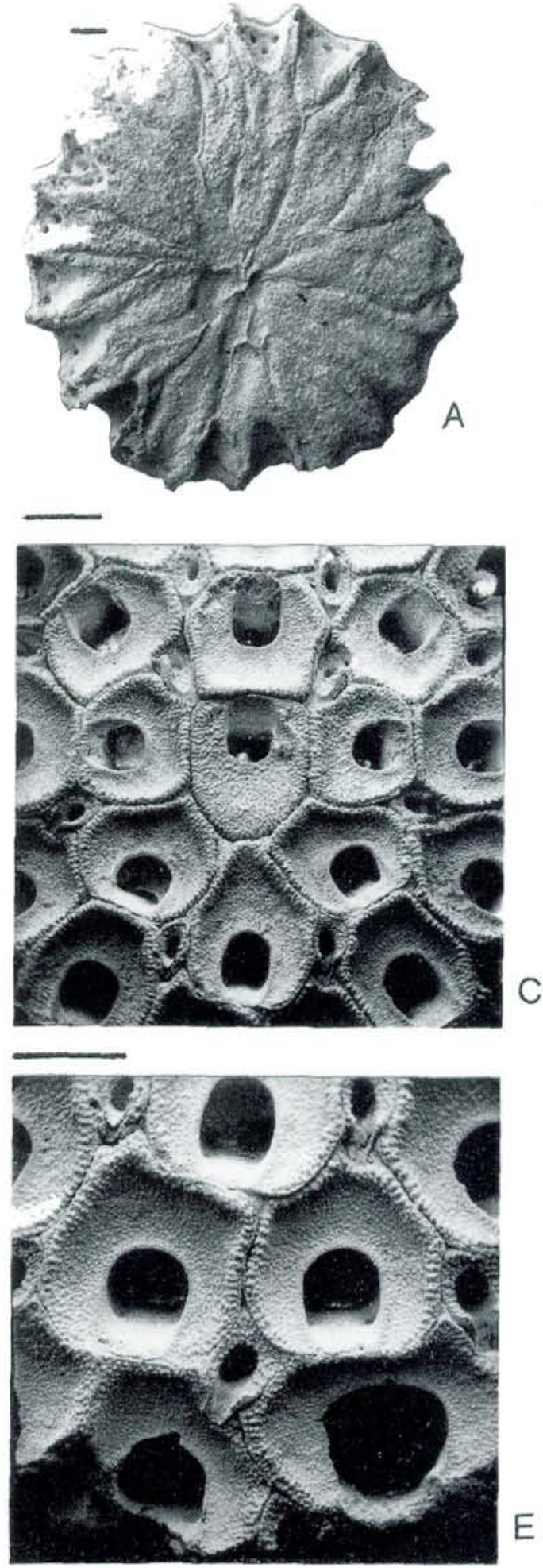
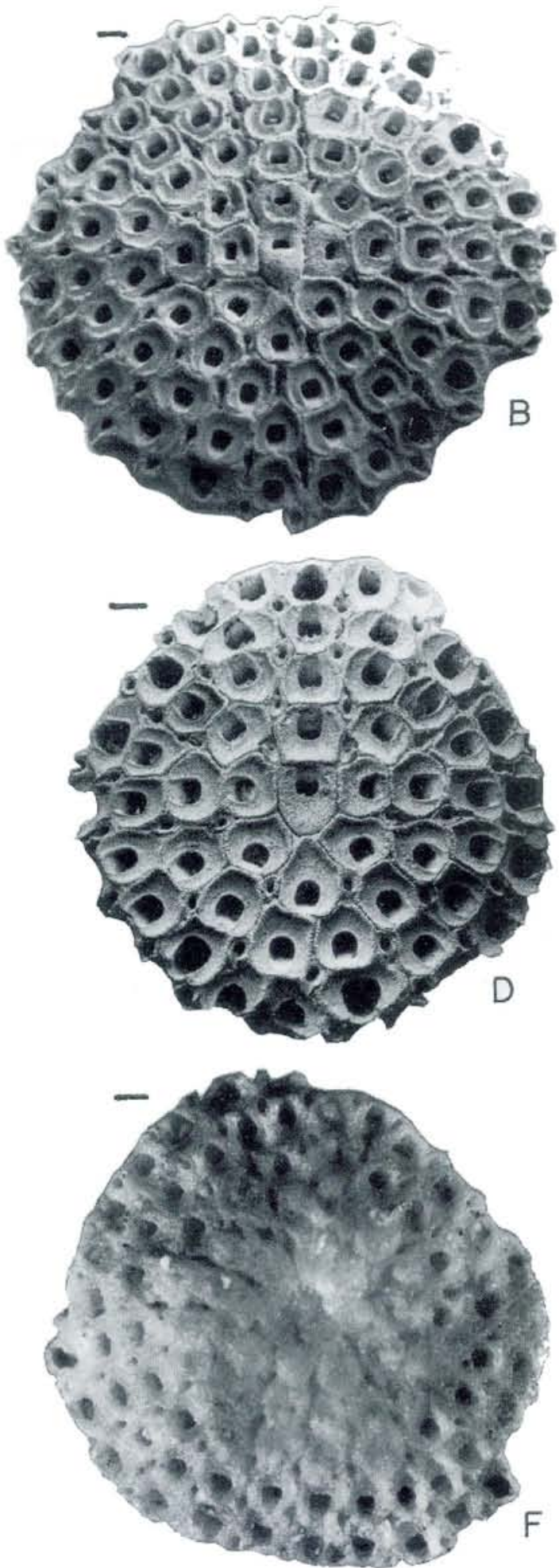

Fig. 3. Lunulites pseudocretacea n. sp. A, basal view of complete colony (MGUH 23089; Ellidshøj). B, frontal view of complete colony; note marginal ovicellate zooids with enlarged opesiae (MGUH 23090; Hemmoor). C, ancestral region of the holotype (D). D, frontal view of the holotype; note marginal ovicellate zooids with enlarged opesiae (MGUH 23088; Ellidshøj). E, autozoids, vibracula and ovicell from the proximal part of the holotype (D). Lunulites cretacea Defrance. F, frontal view of the 'Type' specimen; note the extensive secondary closure of zooids in the ancestral region (Pal. Mus. Paris No. 7876 (Voigt Photocat. No. 3090); conventional photograph). Scale bars $1 \mathrm{~mm}$. 

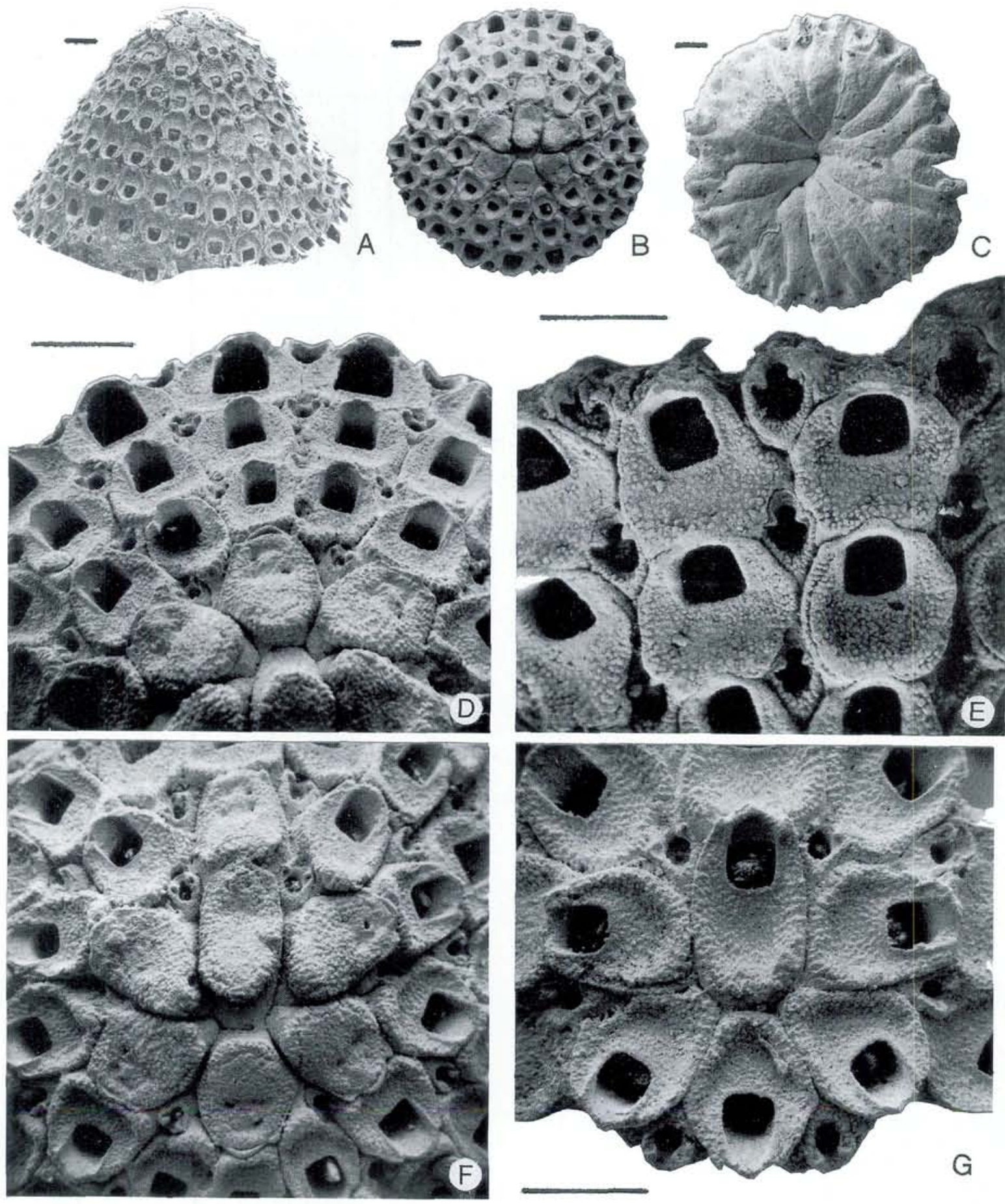

Fig. 4. Lunulites microstoma n. sp. A, lateral view of large, complete colony (Voigt Coll. Photocat. no. 10130; Rørdal). B, frontal view of the holotype; ovicellate zooids visible by their enlarged opesiae (MGUH 23091; Karlstrup, sample 3). C, basal view of complete colony (MGUH 23092; Karlstrup, sample 3). D, autozoids, vibracula and ovicells from the proximal part of the holotype (B). E, autozoids and vibracula (MGUH 23093; Karlstrup, sample 3). F, ancestral region of the holotype (B) with secondary closure. G, ancestral region of very young colony without closure (Voigt Coll. Photocat. no. 6644; Wulmstorf bei Harburg (drift)). Scale bars $1 \mathrm{~mm}$. 
in the Maastrichtian deposits from these areas, the original concept of $L$. cretacea is rather obscure. Later authors have therefore relied on the figures and descriptions given by d'Orbigny (1852, p. 349, Pl. 704, figs 26), generally evading the problem whether d'Orbigny's type is in accordance with the original concept. In spite of the clear text of Defrance (1823, p. 360), d'Orbigny (1852, p. 350) states: 'Nous la rapportons au L. cretacea Defrance, seulement parcequ'elle se rencontre plus communement à Sainte-Colombe (Manche) où M. Defrance l'indique'. None the less, no specimens from Sainte-Colombe are now present in the d'Orbigny Collection in Paris under the catalogue No. 7876, nor have they been listed elsewhere in his catalogue - only specimens from Néhou, Meudon, Tours, Vendôme, and Merpins exist. Moreover, all specimens from the three last mentioned localities belong to other species (see also Beissel, 1865, p. 33). On the other hand one of the specimens from Néhou - a locality not listed by d'Orbigny but mentioned by Defrance - show signs of once having been mounted in wax like most specimens in the d'Orbigny collection used as models for his illustrations. Consequently this specimen (shown here as Fig. 3F) is proposed as a lectotype of Lunulites cretacea Defrance even though it is not in complete agreement with d'Orbigny's figure in regard to the shape and position of the vibracula. Whether this apparent discrepancy should automatically discredit our suggestion is, of course, a crucial problem. But in view of the 'artistic freedom' previously demonstrated in d'Orbigny's illustrations (Voigt, 1972), we feel that our proposal is warranted - if only for the sake of systematic stability.

To add to the overall confusion d'Orbigny (1852) further described $L$. tuberculata, $L$. regularis, $L$. peta loides, $L$. rosacea, and $L$. subconica from SainteColombe, thus making his statement quoted above even more peculiar.

The name pseudocretacea reflects the previous mis use of the name $L$. cretacea for specimens from the northern European chalk.

Stratigraphic range and distribution: Late Campanian and Maastrichtian (brachiopod zones 1-10); chalk facies across the North Sea Basin.

\section{Lunulites microstoma $\mathrm{n} . \mathrm{sp}$.}

Figs $4 A-G$

Holotype: MGUH 23091 (Figs 4B, D, F); Late Maastrichtian (brachiopod zone 10, Karlstrup 3).

Material: Lower Maastrichtian chalk: Denmark (Hvidskud, Jydelejet, Lille Taler); Upper Maastrichtian chalk: Denmark (Rørdal, "Norden", Nr. Uttrup, Bleg kilde, "Danmark", Gudumholm, Nr. Flødal, Skovstrup,
Ellidshøj, Stevns Klint, Karlstrup, Hasselø, Nyvang Gård) and Germany (Hemmoor, Basbeck, plus drift).

Description: Colony small, dome-shaped and massive, with slightly convex to slightly concave basal side; composed of alternating regular, radial rows of autozooids and vibracula. Ancestrula typically more elongate than the surrounding autozooids; surrounded by 6 autozooids and 2 disto-lateral vibracula. Basal wall with extensive secondary thickening and typically totally calcitic, with a slightly uneven surface, crossed by distinct radial furrows corresponding to the lateral walls of autozooidal budding rows; vibracular rows not visible on the basal side.

Autozooids small, more or less quadratic, most often slightly elongate but sometimes also broader than wide; cxryptocyst slightly concave, bound by an inconspicuous mural rim which, lateral to the opesia, forms two inconspicuous nobs; opesia small and elongate, semielliptical to almost quadratic with straight posterior rim; opesia in the central parts of the colonies typically closed by prominent cryptocystal deposits, leaving four minute pores.

Vibracula small, with a somewhat rounded distal end; opesia small and elongate, surrounded by a narrow cryptocyst; a pair of small condyles situated at the distal end of the opesia.

Brooding zooids slightly swollen, recognisable mostly by their larger opesiae.

Remarks: In most respects $L$. microstoma $n$. sp. is similar to $L$. pseudocretacea and $L$ cretacea Defrance (cf. p. 190 and Fig. 3F). However, both these species are considerably larger in all dimensions, and since no intermediate forms are known and, moreover, the species have distinct geographical and stratigraphic distributions, they are kept separate. Except for the Lunulites growth form $L$. microstoma is very similar to $P$. aquensis Brydone (nom. nov. for $P$. elegans Beissel) which, however, has a slightly different stratigraphic distribution in the middle Maastrichtian. From the Danian species L. salthomensis Berthelsen our new species is distinguished by the lack of pores in the basal wall.

The name microstoma is derived from mikros, greek for small and stoma, greek for aperture/mouth.

Stratigraphic range and distribution: Maastrichtian (very rare in brachiopod zones 3 and 6; abundant in brachiopod zones 8-10); chalk facies in the northern part of the North Sea Basin.

\section{Lunulites conulus n. sp.}

\section{Figs 5C-F}

Holotype: Voigt Coll., Photocat. no. 438 (Figs 5C-E); late Early Maastrichtian, Lunderggård). 

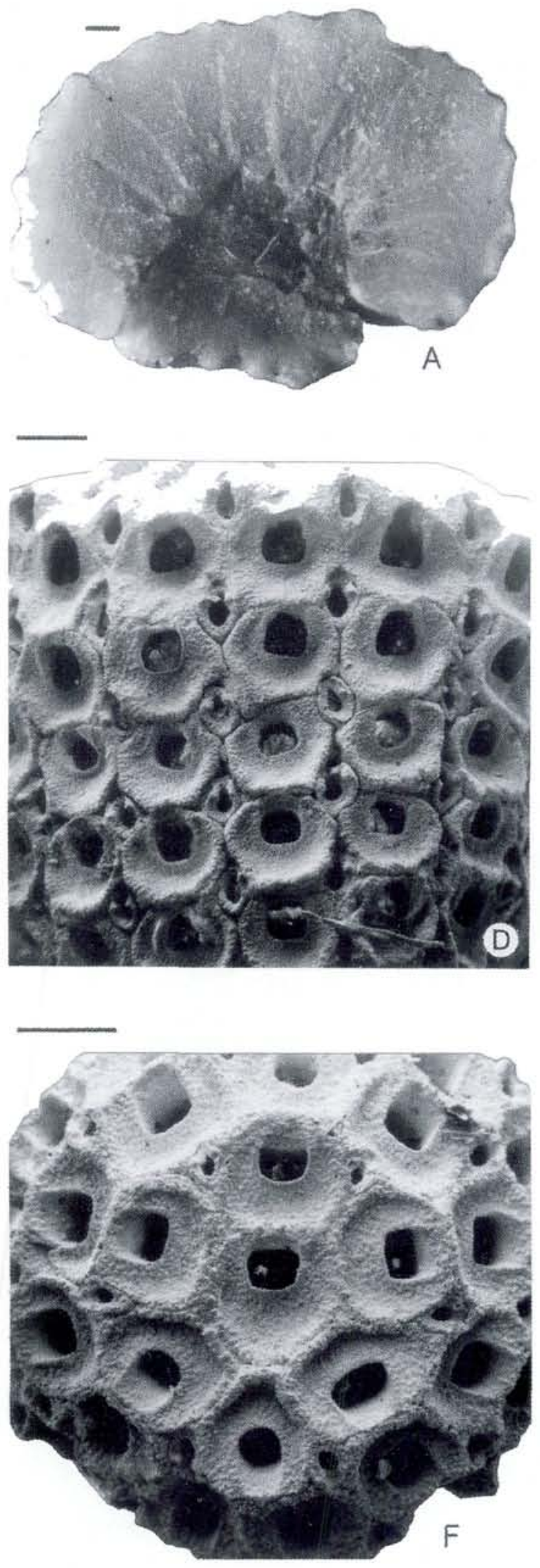

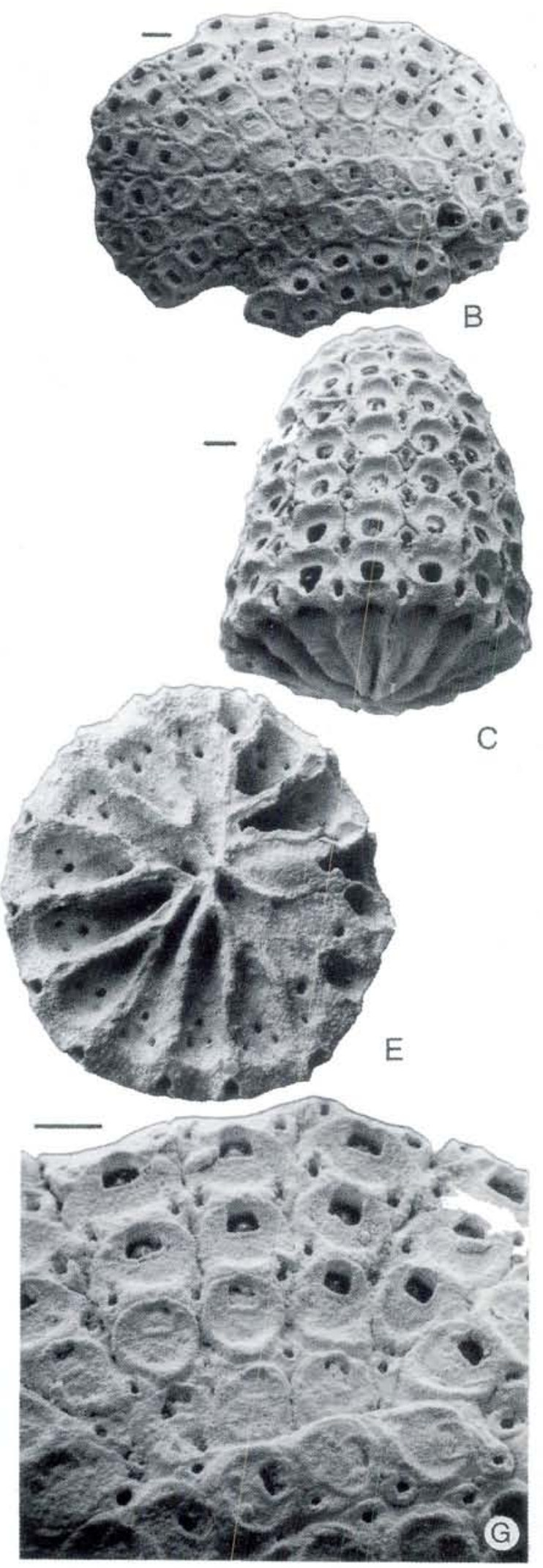

Bulletin of the Geological Society of Denmark 
Material: Lower Maastrichtian chalk: Denmark (Rørdal); Upper Maastrichtian chalk: Denmark (Rørdal, Blegkilde, Gudumlund, Lundergård) and the North Sea.

Description: Colony small and massive, cone-shaped to almost cylindrical; composed of alternating regular rows of autozooids and vibracula radiating from a central ancestrula; zooidal rows typically branching 1 or 2 times only. Ancestrula of the same shape but slightly larger than the surrounding six autozooids. Basal side formed by the distal walls of the terminal zooids; flat to convex, often with distinct radial ridges formed by the lateral walls of incomplete zooids.

Autozooids almost quadratic; granulated, only centrally slightly depressed and bound by a distinct mural rim; opesiae appear almost quadratic with slightly curved distal margins.

Vibracula symmetric, narrow and elongated; with a small oval opesia in the proximal end, surrounded by a narrow cryptocyst; a pair of condyles developed in the distal half.

Ovicells strongly arched but not very conspicuous; recognisable mostly through the more elongate opesia of brooding zooids.

Remarks: In the unusual construction of the massive colony $L$. conulus $\mathrm{n}$. sp. resembles $L$. sella Marsson, from which it is distinguished by its budding pattern with regular rows of alternating autozooids and vibracula.

Conulus is diminutive of conus, latin for cone.

Stratigraphic range and distribution: Mid-Maastrichtian (rare in brachiopod zone 7-8); chalk facies in the northernmost part of the North Sea basin.

\section{Lunulites vespertilio $\mathrm{n} . \mathrm{sp}$.}

Figs 5A-B, G

Holotype: Voigt Coll., Photocat. no. 6650 (Figs 5A-B, G); Late Maastrichtian, Hemmoor 142).

Material: Upper Maastrichtian chalk: Germany (Hemmoor).

Description: Both known specimens are regenerated from fragments, but the colony is most probably circular with a rather shallow concave basal side and a more strongly convex frontal side; composed of radiating rows of autozooids alternating with less regular, not continuous and commonly double rows of vibracula. Ancestrula not known. Basal wall calcitic and with extensive secondary thickening with small, but distinct radial ridges corresponding to lateral walls of autozooidal rows; vibracular rows not visible on the basal side.

Autozooids more or less quadratic, often even wider than long in distal parts of the colony; cryptocyst flat and even, surrounded by an indistinct mural rim; opesia comparatively small, almost semicircular with straight proximal margin and slightly wider than long; most opesiae in the older parts of the colony sealed off by growth of a cryptocystal calcareous lamina.

Vibracula very small and elongate, with a tapering distal margin; a prominent flat cryptocyst is developed proxial to the small rounded opesia, continuing in a pair of lateral condyles. Ovicells not observed.

Remarks: The frequent occurrence of two vibracula in association with each autozooid is a very unusual character among Cretaceous Lunulites, otherwise known only in $L$. pyripora Canu from the Maastrichtian of Madagascar (Buge, 1951). However, this species have relatively larger, elongate opesiae surrounded by a distinct cryptocystal rim and, furthermore, it is characterised by an apparently porous basal wall. It should be stressed that $L$. vespertilio $\mathrm{n}$. $\mathrm{sp}$. is known from only two specimens, and that smaller areas within both have a more traditional vibracular pattern.

The name vespertilio, latin for bat, refer to the shape of the opesia with its disto-lateral pair of vibracula.

Stratigraphic range and distribution: Late Maastrichtian (very rare); chalk facies in the central part of the North Sea Basin.

\section{Lunulites patens $\mathrm{n} . \mathrm{sp}$.}

Figs $6 \mathrm{~A}-\mathrm{G}$

Holotype: MGUH 23095 (Fig. 6B); Late Maastrichtian (brachiopod zone 9, Nr. Flødal 1).

Material: Upper Maastrichtian chalk: Denmark (Gudumholm, Nr. Flødal, Skovstrup, Ellidsh øj, Fjerritslev) and Germany (Hemmoor).

Description: Colony circular and dome-shaped; com-

Fig. 5. Lunulites vespertilio $\mathrm{n}$. $\mathrm{sp}$. A-B, basal and frontal view of the holotype (basal view in conventional photograph); the budding pattern clearly indicates that this specimen is regenerated from a fragment (Voigt Coll. Photocat. no. 6650; Hemmoor sample 142). G, Enlarged, frontal view of the holotype (A-B). Lunulites conulus n. sp. C, lateral view of the holotype (Voigt Coll. Photocat. no. 438; Lundergård). D, autozooids and vibracula from the distal part of the holotype (C); slightly enlarged opesiae may represent ovicels. $\mathrm{E}$, basal view of the holotype (C); note the apparant lack of zooidal basal walls. $\mathrm{F}$, ancestral region of young colony (MGUH 23094; Rørdal, sample 2). Scale bars $1 \mathrm{~mm}$. 

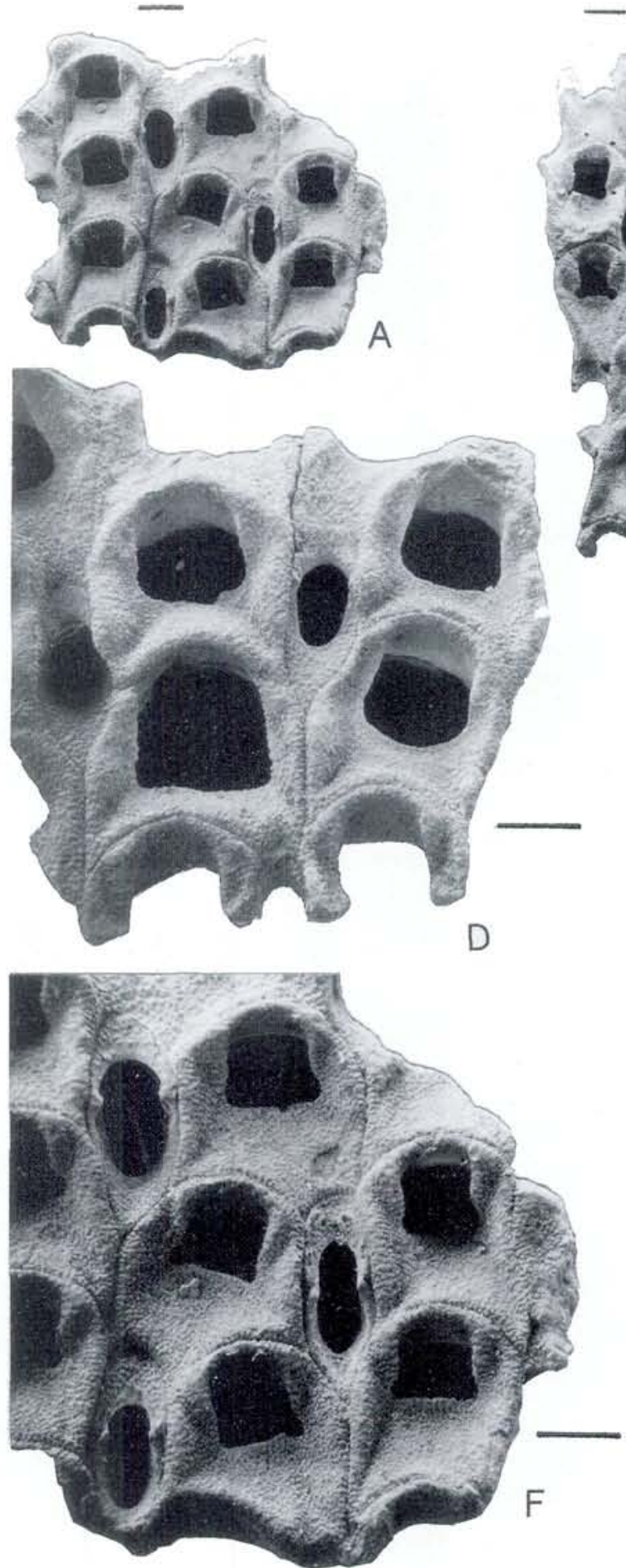

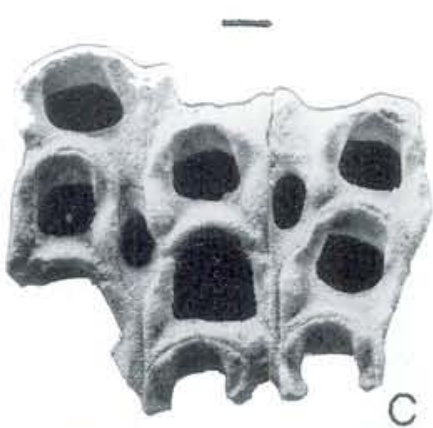

C
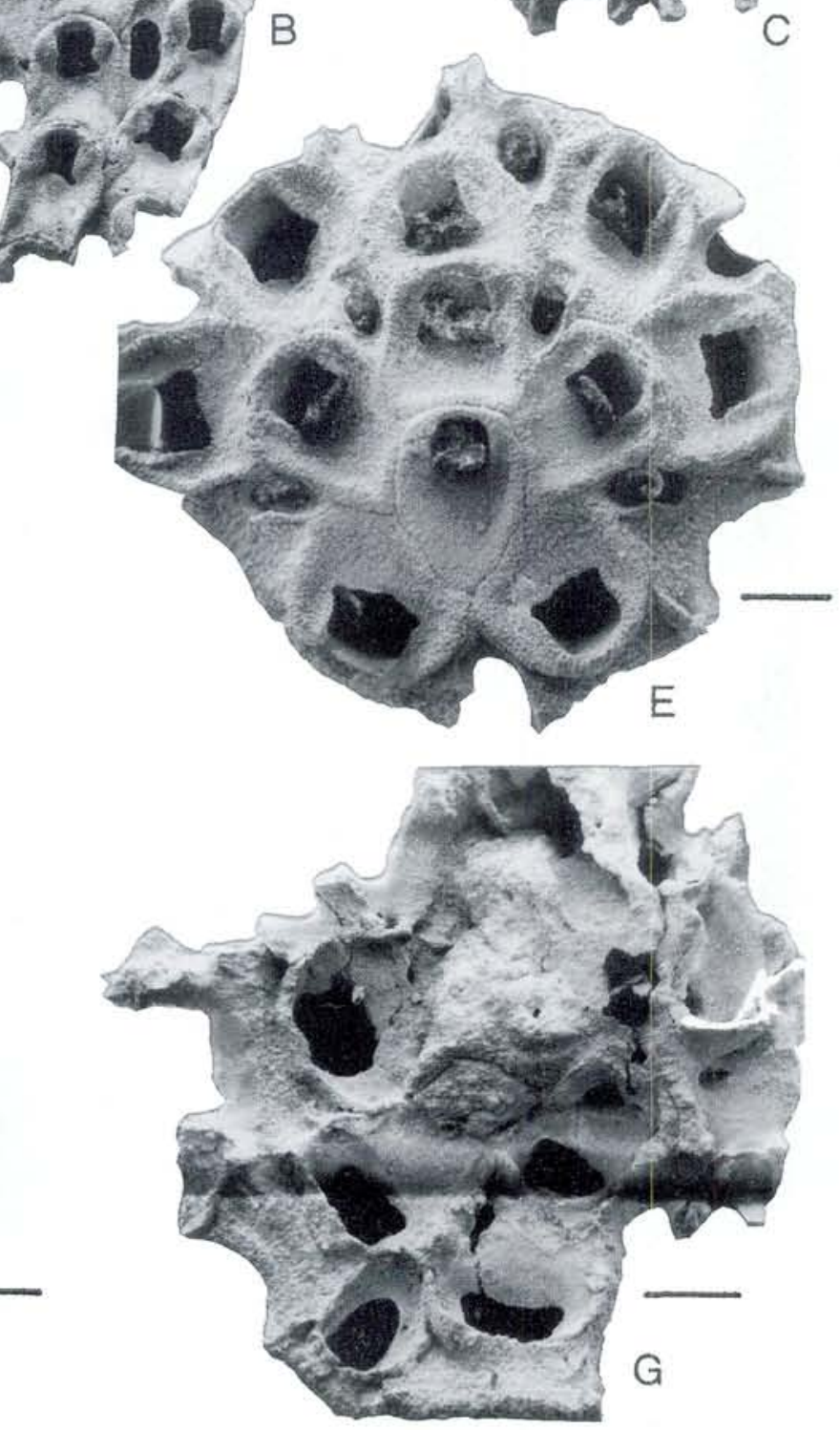

Fig. 6. Lumulites patens $\mathrm{n}$. sp. A. Frontal view of colony fragment with fairly small opesia (MGUH 23097; Hemmoor, sample 139). B, frontal view of colony fragment with small, trifoliate opesiae; holotype (MGUH 23095; Nr. Flødal, sample 1). C, frontal view of colony fragment with large opesia; the very large central opesium represents an ovicellate zooid (MGUH 23098; Hemmoor, sample 124). D, enlarged view of C. E, ancestral region of very young colony (MGUH 23099; Gudumholm, sample 1). F, ) enlarged view of A. G, basal view of ancestrular region; note that the basal wall has been dissolved (diffuse black horizontal line represents unavoidable charging in the scanning procedure) (MGUH 23096; Nr. Flødal, sample 1). Scale bars $1 \mathrm{~mm}$. 

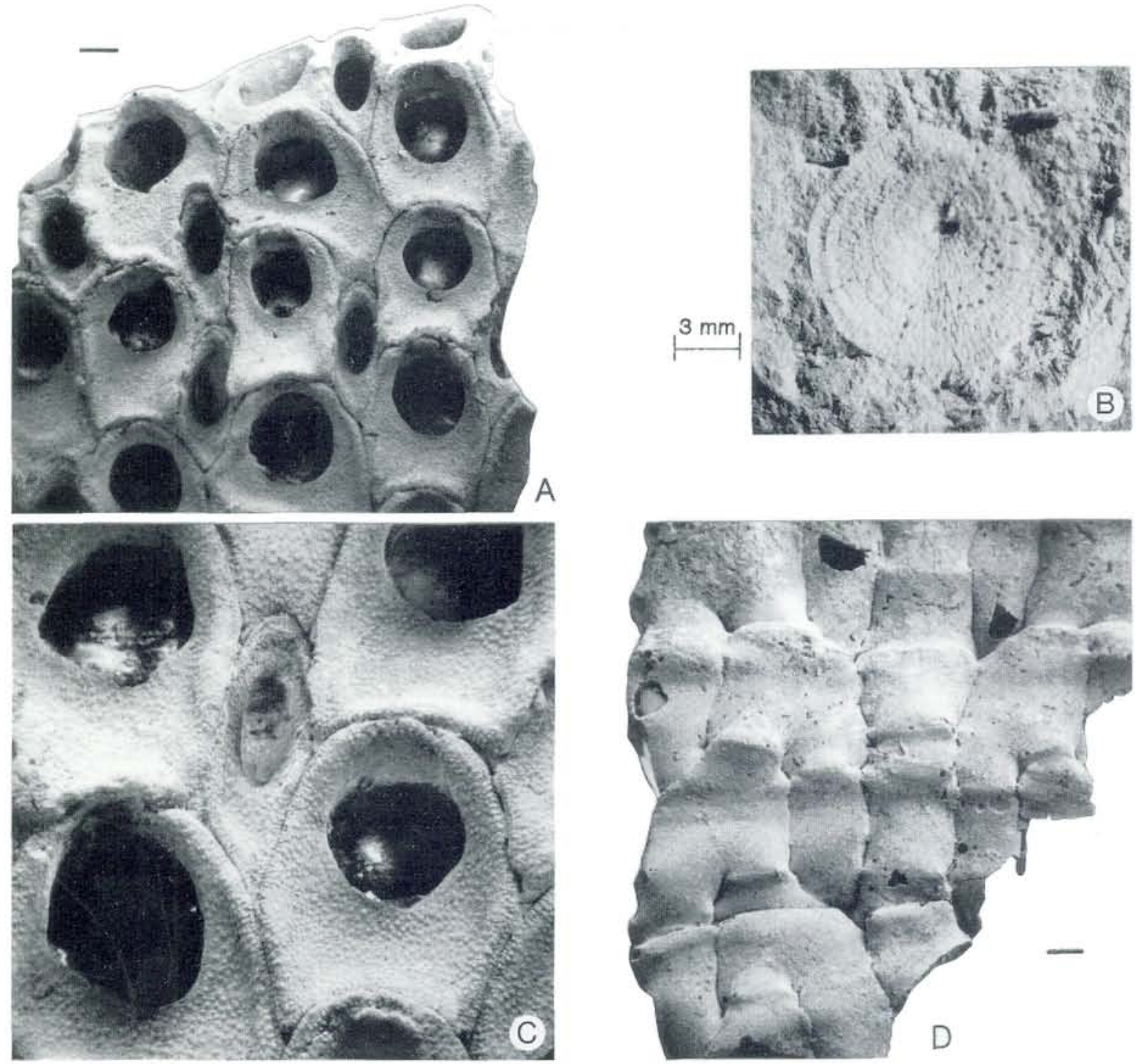

Fig. 7. Lumulites immensa n. sp. A, frontal view from the distal margin of the holotype fragment (MGUH 23100; Stevns Klint). B, basal view of complete colony still adhering to the chalk matrix; note the slightly asymmetrical system of concentric growth lines surrounding the fairly small substrate (MGUH 23101; Stevns Klint). C, autozooids and vibraculum from the holotype (A). D, basal view of colony fragment; note the somewhat irregularly distributed transverse beads which together form the growth lines visible in B (MGUH 23102; Stevns Klint). Scale bars $1 \mathrm{~mm}$ except in B. 
posed of rather irregular radiating rows of autozooids; vibracula typically isolated, commencing new budding rows or dispersed among the autozooids. Ancestrula variable, more or less similar to, but longer than the surrounding 5 or 6 autozooids. Basal wall missing, indicating that it was originally aragonitic.

Autozooids sub-quadratic and rounded distally; with a granulated, variously developed, deeply depressed cryptocyst bound by a swollen mural rim; opesiae at least half as long as the zooecia, the shape and size varies from rounded rectangular to semielliptical with distinct opesiular indentations; the margin of the opesiae finely denticulated.

Vibracula rather irregular in outline, typically as long as autozooids and half as wide, but considerably smaller near the ancestrula; opesia elongate oval, surrounded by a weakly developed cryptocyst; a pair of small condyles found in the distal half.

Ovicells strongly arched but relatively indistinct, recognisable on the very large opesiae of brooding zooids.

Remarks: The autozooids of $L$. patens $n$. sp. are somewhat like in L. patelliformis Marsson which, however, is distinguished by its regular, alternating rows of autozooids and vibracula and by its calcitic basal wall; furthermore, L. patelliformis has comparatively smaller opesiae, especially in fertile zooecia. It should be mentioned that because of the dissolution of the basal wall L. patens is very fragile so only small complete colonies have been found; thus very little can be inferred about the ontogenetic or astogenetic significance of the unusual zooecial variation recorded in this species.

The name patens, latin for open, refer to the dissolved, originally aragonitic basal walls, which leaves the opesiae visible from both sides.

Stratigraphic range and distribution: Late Maastrichtian (brachiopod zones 8-9); chalk facies in the northern part of the North Sea Basin.

\section{Lunulites immensa $\mathrm{n}$. sp.}

Figs 7A-D

Holotype: MGUH 23100 (Figs 7A, C); Late Maastrichtian (brachiopod zone 10, Stevns Klint).
Material: Lower Maastrichtian chalk: Denmark (Hvidskud); Upper Maastrichtian chalk: Denmark ("Danmark", Skovstrup, Stevns Klint).

Description: Colony large and almost flat, composed of regular rows of autozooids radiating from a somewhat excentric ancestrula; vibracula isolated, rather irregularly distributed in the budding pattern, both in connection with bifurcations of budding rows and within such rows. No well preserved ancestrula known; in the single complete specimen known the ancestrula encrusts a fairly large substrate (Fig. 7B). Basal wall calcitic and comparatively thin, with distinct radial furrows corresponding to lateral walls of zooidal budding rows, and with more irregularly dispersed transverse furrows and beads.

Autozooids very large, rounded distally and with almost parallel sides; typically longer than wide but sometimes also as long as wide; cryptocyst flat and finely granulated, mostly weakly developed and bound by a prominent mural rim; opesiae usually more than half the length of the zooecia, with a rounded triangular to almost circular shape depending on the outline of the zooecia.

Vibracula elongate, with narrowly rounded distal margin, typically shorter than the autozooids and less than half as wide; opesiae rounded elongate, somewhat tapering towards the posterior and with a finely denticulated rim, surrounded by a rather steep cryptocyst; condyles not or very weakly developed.

Ovicells small, moderately arched; opesiae of brooding zooids not noticeably enlarged.

Remarks: In the zooidal characters $L$. immensa is somewhat similar to the P. schmidi n. sp. group; however, it is separated from all species in this group by the exceptional zooidal dimensions. The assignment of this species to the genus Lunulites is due mostly to the shape of the colony and the assumed free mode of life, in most other respects $L$. immensa appears more primitive than species traditionally referred to that genus.

$L$. immensa is named for its unusual size in both zooidal and colonial dimensions.

Stratigraphic range and distribution: Maastrichtian (rare in brachiopod zones 5 and 8-10); chalk facies in the northernmost part of the North Sea Basin.

Fig. 8. Lunulites foveolata $\mathrm{n}$. sp. A, basal view of colony fragment; note the evenly distributed, coarse depressions (MGUH 23104; Lundergård). B, frontal view of the holotype (MGUH 23103; Gudumholm, sample 1). C, frontal view of the distal part of a very large colony fragment (MGUH 23105; Lundergård). D, autozooids and vibracula from the distal part of the holotype (B). E, ancestral region of the holotype (B); the central, somewhat tilted autozooid is NoT the ancestrula which is completely overgrown during the later astogeny. F, distal margin showing autozoids, vibracula and two ovicells recognizable through their shallow hood at the distal margin (MGUH 23106; Nr. Flødal, sample 1). Scale bars $1 \mathrm{~mm}$. 

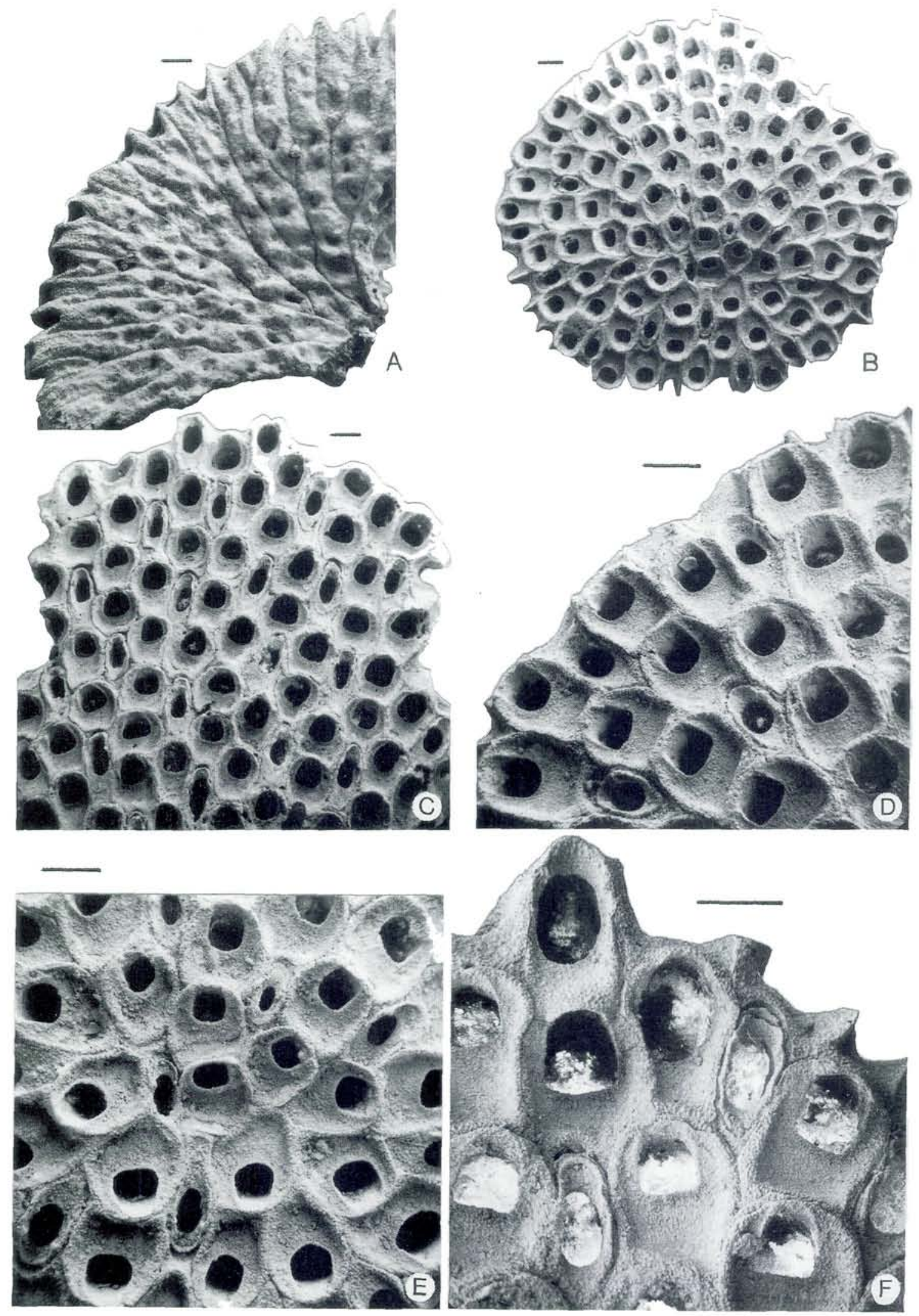

Håkansson \& Voigt: New free-living bryozoans 
Lunulites foveolata $\mathbf{n}$. sp.

Figs 8A-F

Holotype: MGUH 23103 (Figs 8B, D-E); Late Maastrichtian (brachiopod zone 8, Gudumholm 1).

Material: Lower Maastrichtian chalk: Denmark (Rørdal); Upper Maastrichtian chalk: Denmark (Rørdal, "Danmark", Blegkilde, Gudumholm, Skovstrup, Nr. Flødal, Smidie, Ellidshøj, Lundergård, Stevns Klint, Erslev, Kjølby Gård).

Description: Colony in young stages fan-shaped with a marginal ancestrula, but rapidly it develops into a circular, slightly convex colony with a radial budding pattern; composed of somewhat irregular rows of autozooids; vibracula isolated, distributed regularly in the budding pattern, typically in connection with bifurcations of budding rows, but occasionally also within such rows. Ancestrula similar to the following autozooids except for a tapering proximal end; followed by 2 autozooids and 1 vibraculum or 1 autozooid and 2 vibracula; ancestrula in later stages more or less overgrown. Basal wall calcitic and comparatively thick, with distinct radial furrows initially corresponding to zooidal budding rows, but in later stages radiating from a more central point; between the furrows are found a more or less regular series of round depressions (with small pores?), typically in a number corresponding to $1-2$ per zooid.

Autozooids irregularly hexagonal to pear-shaped; with an almost flat cryptocyst bound by a distinct, sharp mural rim; opesiae typically almost quadratic with rounded corners, but larger and more elongate near the growing edge.

Vibracula distally rounded, commonly longer than the autozooids and relatively wide; opesiae elongate elliptical, situated centrally and surrounded by a narrow cryptocyst; a pair of very inconspicuous condyles are found in the distal half.

Ovicells rather strongly arched, opesiae of brooding zooids not noticeably enlarged.

Remarks: The astogeny of $L$. foveolata $\mathrm{n}$. sp. is practically identical to that of $L$. beisseli Marsson and rather similar to the astogeny of $P$. schmidi n.sp. (cf. below) (Håkansson 1974 and unpublished). However, $L$. foveolata is distinguished from $L$. beisseli by the characteristic depressions (pores?) on the basal side, the sharp,projecting mural rims and the central opesiae of the vibracula. From $P$. parva n. sp. and, especially, $P$. schmidi this new species is distinguished by the basal depressions and its more fully developed Lunulitesgrowth form in older stages.

The name foveolata refers to the small depressions on the basal side (fovea, latin for pit).

Stratigraphic range and distribution: Mid- to Late
Maastrichtian (brachiopod zones 7-10); chalk facies in the northernmost part of the North Sea Basin.

\section{Pavolunulites schmidi n. sp.}

Figs 9D-E, G-H

Holotype: MGUH 23109 (Fig. 9H); Late Maastrichtian (Hemmoor, sample 132).

Material: Upper Maastrichtian chalk: Denmark (Lundergård) and Germany (Hemmoor).

Description: Colony in younger stages broadly fanshaped and rather flat, with a somewhat jagged margin; composed of irregular rows of autozooids radiating from the marginal ancestrula; in very old stages a circular, more arched colony form is obtained by accelerated growth of a pair of proximo-lateral lobes which eventually fuses, leaving an open, narrowly Vshaped slit around the proximal end of the ancestrular region; vibracula typically isolated, dispersed slightly irregularly in the budding pattern, commonly in connection with bifurcation of budding rows. No well preserved ancestrula known, but probably largely similar to the following autozooecia except for a tapering proximal end; ancestrula followed by 2 autozooids and 1 vibraculum. Basal wall calcitic and comparatively thin, with slightly irregular furrows corresponding to lateral walls of budding rows and short, terminated side branches on these furrows connected with vibracula; more or less distinct transverse lines are frequently developed.

Autozooids large and variable, pentagonal or hexagonal in outline, most commonly elongate but sometimes also quadratic or even wider than long; cryptocyst rather weakly developed, gradually passing into the indistinct mural rim; opesiae large and variable, depending on the shape of the zooid, surrounded by a finely denticulated rim.

Vibracula somewhat narrower than autozooids but of the same length or even longer, the longitudinal axes slightly divergent from that of the neighbouring autozooids, the margin rounded distally; opesiae large, elliptically rounded with a finely denticulated rim, surrounded by a rather narrow cryptocyst; condyles barely present.

Zooids with larger, often more broadly triangular opesiae 'which have slightly arched distal margins' are assumed to have had a brooding function.

Remarks: The very peculiar late astogeny of this species reminds of the development found in $L$. beisseli Marsson and $L$. foveolata $n$. sp. These two species have similar early stages, but rapidly they develop more compact, circular colonies with no open slit proximal to the ancestrula (Håkansson, 1974 and unpublished). Thus $P$. schmidi n.sp. occupies an intermediate position be- 

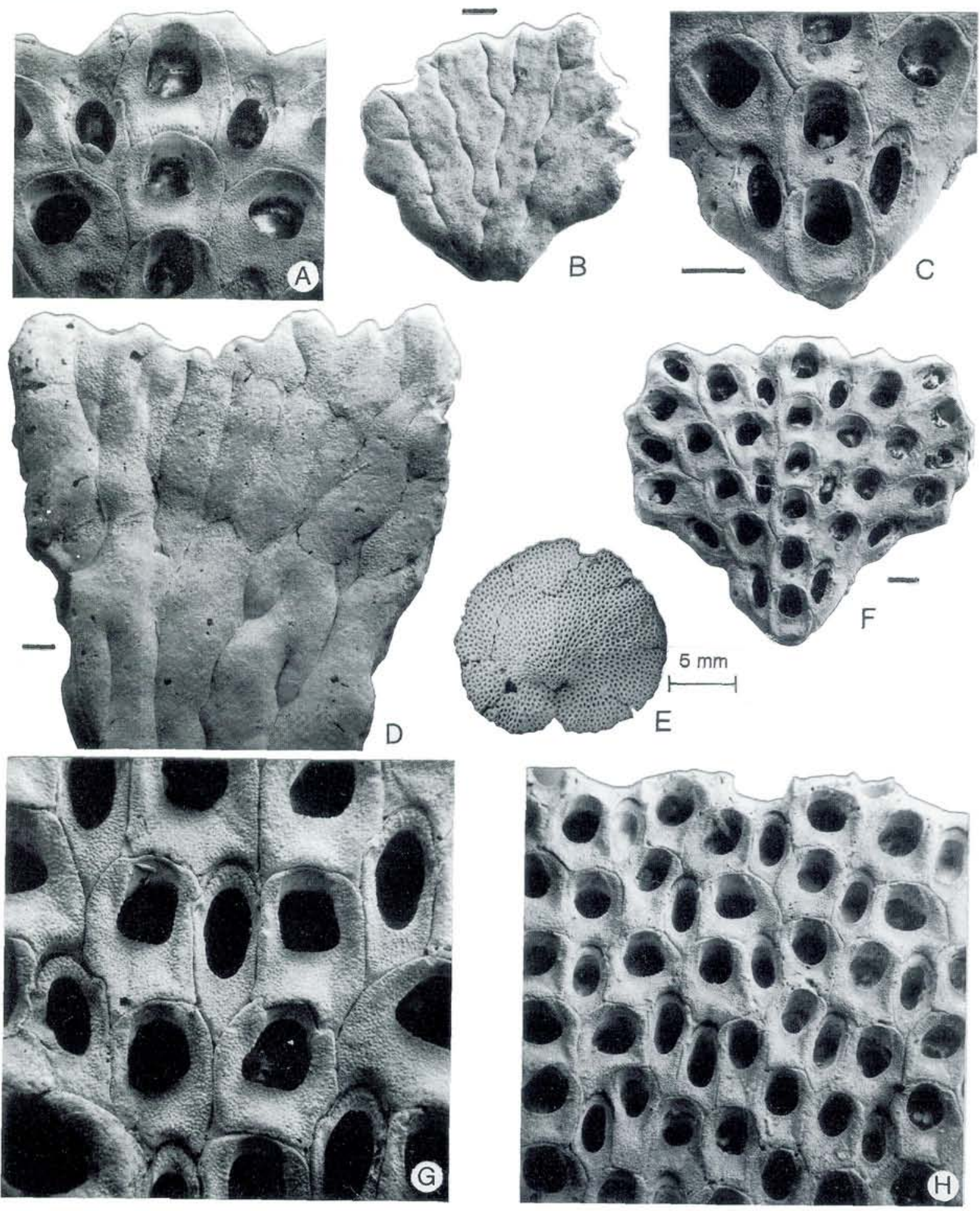

Fig. 9. Pavolunulites parva n. sp. A, autozooids and vibracula at the distal margin of the holotype (F). B) Basal view of complete specimen (MGUH 23108; Hemmoor, sample 134). C, ancestral region of the holotype (F). F, frontal view of the holotype (MGUH 23107; Hemmoor, sample 134). Pavolunulites schmidi n. sp. D, basal view of colony fragment (MGUH 23110; Hemmoor, sample 14). E, frontal view of complete colony; note that a near circular shape has been achieved late in astogeny by proximo-lateral growth of two broad lobes (MGUH 23111; Hemmoor). G, Autozooids and vibracula (MGUH 23112; Hemmoor, sample 14). H, frontal view of the holotype fragment (MGUH 23109; Hemmoor, sample 132). Scale bars $1 \mathrm{~mm}$ except in E. 
tween the latter two species and other members of the form genus Pavolunulites with the persistent fan-shaped astogeny typical for this genus. Apart from the astogenetical differences, $P$. schmidi is separated from $L$. beisseli by its considerably larger, more rounded opesiae and from $L$. foveolata by the lack of basal depressions. From the similar P. parva n. sp. P. schmidi is distinguished by having considerably larger zooidal dimensions in all stages; $P$. richteri (v. Hagenow) has narrow, more arched colonies and high, sharp mural rims, whereas $P$. cochlearis (Marsson) is distinguished by the comparatively larger opesiae and the narrow, slitlike appearance of the vibracula.

P. schmidi is named after Prof. Dr. Fr. Schmid who was in charge of the detailed paleontological investigations of the important Maastrichtian succession at Hemmoor (Schmid 1982); Prof. Schmid collected the sole complete specimen known of this species.

Stratigraphic range and distribution: Late Maastrichtian (rare in brachiopod zones 8 and 9), Chalk facies in the northern part of the North Sea Basin.

\section{Pavolunulites parva $\mathbf{n}$. sp.}

Figs 9A-C, F

Holotype: MGUH 23107 (Fig. 9A, C, F); Late Maastrichtian (Hemmoor, sample 134).

Material: Upper Maastrichtian chalk: Germany (Hemmor, Basbeck, plus drift) and Belgium (Hallembaye); Upper Maastrichtian calsiltites: Belgium (Eben Emael) and the Netherlands (St. Pietersberg, Geultal).

Description: Colony flat and broadly fan-shaped, sometimes with a jagged outline; composed of rather regular rows of autozooids radiating from the marginal ancestrula, occoasionally forming a completely symmetric budding pattern; vibracula isolated, confined to points of branching in the budding rows and to the permanent lateral margins of the colony. Ancestrula of the same size and shape as the following autozooids; followed by 1 autozooid and 2 vibracula or 2 autozooids and 1 vibraculum. Basal wall calcitic and rather thin, smooth with faint, regular furrows corresponding to the lateral walls of zooidal budding rows.

Autozooids small and elongate hexagonal with curved distal margins; cryptocyst depressed, passing gradually into the indistinct mural rim; opesiae rounded elongate, half the length of the zooecia or slightly larger.

Vibracula elongate with a rounded distal margin, of the same length as the autozooids but only slightly more than half the width; opesiae large, elliptically rounded, surrounded by a narrow steep cryptocyst; condyles barely present.

Ovicells slightly arched, recognizable mostly by the larger, more triangular opesiae of brooding zooids.

Remarks: $P$. parva n. sp. is rather similar to $P$. moenensis $\mathrm{n}$. sp. in both general dimensions and colony shape; however, it is distinguished by having larger, always rounded opesiae which lack opesiular indentations. From $P$. schmidi n. sp. this new species is separated by attaining only approximately half the zooidal dimensions.

P. parva is named for its comparatively small colonies (parva, latin for small).

Stratigraphic range and distribution: Late Maastrichtian; chalk and calsiltites in the southern part of the North Sea Basin.

\section{Pavolunulites moenensis $\mathrm{n}$. sp.}

Figs 10D, F-G, I-J

Holotype: MGUH 23116 (Figs 10F, I); Early Maastrichtian (brachiopod zone 6, St. Taler).

Material: Lower Maastrichtian chalk: Denmark (St. Taler, Ll. Taler).

Description: Colony thin and almost flat, broadly fanshaped; composed of rather regular rows of autozooids radiating from the marginal ancestrula, occasionally forming a symmetric budding pattern; vibracula isolated, typically confined to pointsof branching in zooidal budding rows but rarely also within such rows. Ancestrula of the same size and shape as the following autozooids; followed by 2 autozooids and 1 vibraculum or 1 autozooid and 2 vibracula; basal wall calcitic and

Fig. 10. Pavolunulites insolita n. sp. A, frontal view of holotype; note lateral ovicell with enlarged opesium (MGUH 23113; Hvidskud, sample 3). B, distal fragment of colony with median ovicell (MGUH 23114; Hvidskud, sample 3). C, ancestrular region of holotype (A). E, basal view of near complete colony; note distally confluent budding rows (MGUH 23115; Hvidskud, sample 3). Pavolunulites moenensis n. sp. D, frontal view of asymmetrical, complete colony (MGUH 23117; Ll. Taler). F, frontal view of holotype (MGUH 23116; Ll. Taler). G, basal view of symmetrical, complete colony (MGUH 23118; St. Taler). I, autozooids and vibracula from the holotype; note broadly spatulata vibracula with rounded opesiae (F). J, Ancestrular region of colony D. Pavolunulites siemersi Voigt. H, autozooids and vibracula shown for comparison (Voigt Coll. Photocat. No. 11541c; Tornesch near Elmshorn, Germany). Scale bars $1 \mathrm{~mm}$. 


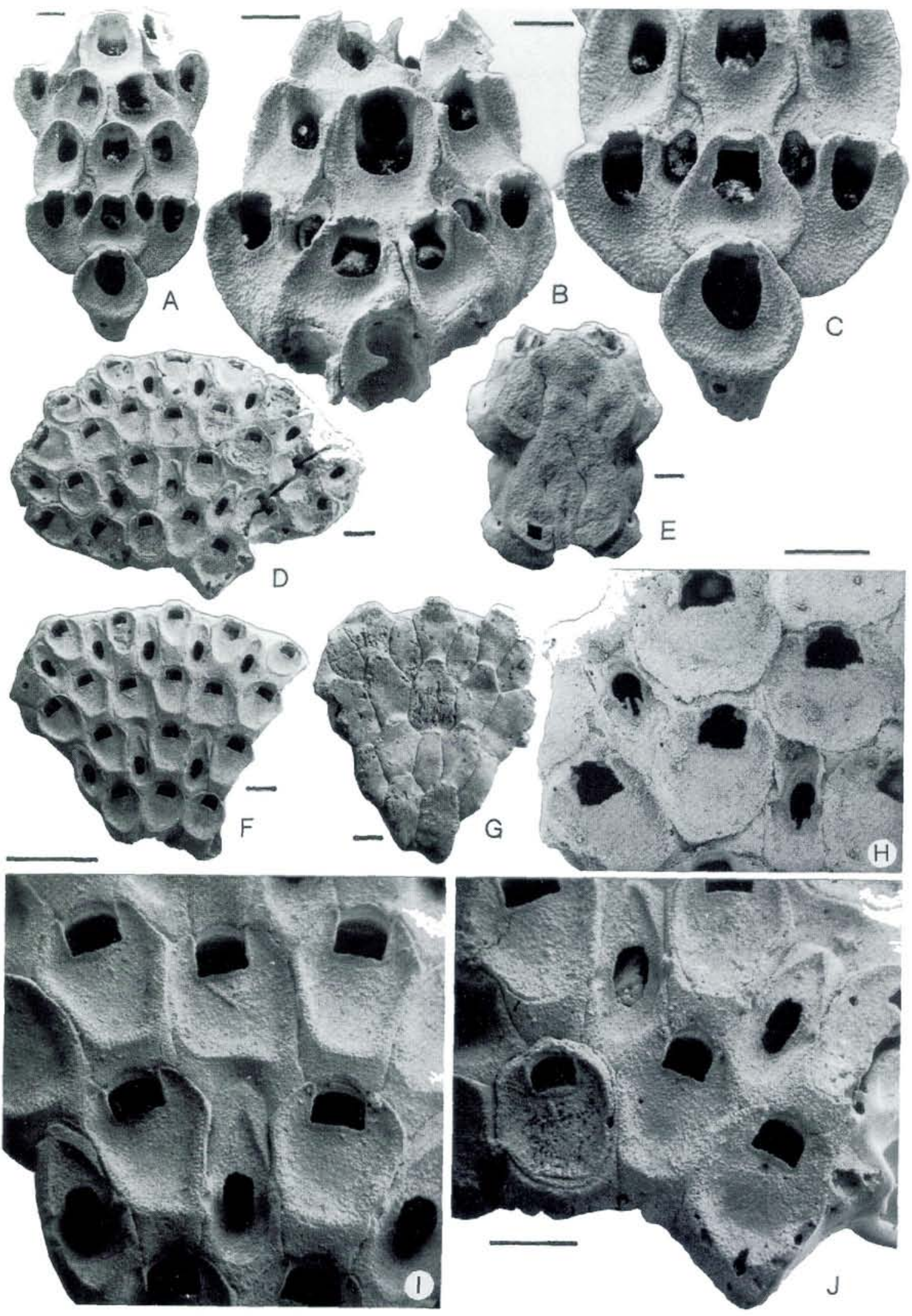


thin, with zigzag furrows corresponding to the lateral walls of zooidal budding rows and commonly with less distinct beads in connection with transverse walls.

Autozooids small and shallow, hexagonal with rounded distal margin; cryptocyst extensive and flat, somewhat depressed and bound by a broad mural rim; opesiae small, semicircular to rounded rectangular, commonly with indistinct opesiular indentations.

Vibracula longer than the autozooids but only half as wide, broadly rounded distally; with a small oval opesia in the proximal half, surrounded by a cryptocyst, which distal to the opesia is forming a narrow, triangular area bound by a broad flat mural rim; condyles not or only faintly developed. Ovicells not observed.

Remarks: In the colony characters $P$. moenensis n. sp. show resemblance to $P$. parva $\mathrm{n}$. sp. which, however, have relatively much larger opesiae, different vibracula and straighter furrows on the basal wall. $P$. moenensis is distinguished from $P$. siemersi Voigt (cf. Fig. 9H) by the structure of its vibracula, its comparatively smaller opesiae, and by its flat, more smooth basal side.

P. moenensis is named after the danish island Møn, which holds its only known occurrence.

Stratigraphic range and distribution: Late Early Maastrichtian (rare in brachiopod zone 6); chalk in the northern part of the North Sea Basin.

Pavolunulites insolita n. sp.

Figs 10A-C, E

Holotype: MGUH 23113 (Figs 10A, C); Early Maastrichtian (brachiopod zone 5, Hvidskud 3).

Material: Lower Maastrichtian chalk: Denmark (Hvide Klint, Gedser, Hvidskud).

Description: Colony small and ribbon-like, transversely arched, typically highly symmetrical; composed of few, short rows of autozooids, the first row following the longitudinal axis of the colony and subsequent rows directed obliquely towards this axis; few vibracula inserted regularly in the budding pattern. Ancestrula variously shaped, larger and often with longer opesia than the following three autozooids. Basal wall calcitic and thin, with longitudinal furrows corresponding to the lateral walls of budding rows; vibracula not visible on the basal side.
Autozooids polymorphic, size and shape depending on the position in the budding pattern; cryptocyst mostly flat, bound by a thin, sharp mual rim which distally projects strongly towards the longitudinal axis; opesiae elongate and rounded, approximately half the length of the zooecia, the shape highly dependent on the position in the budding pattern, lateral opesiae slightly rotated towards the longitudinal axis.

Vibracula small, elongate and slightly asymmetrical, pointing towards the longitudinal axis with tapering distal and proximal margins; a narrow cryptocyst surrounds the central, oval opesia; a pair of small condyles found in the distal half.

Ovicells large and moderately arched; brooding zooids with larger opesia, situated in various positions in the budding pattern.

Remarks: $P$. insolita n. sp. is in many respects somewhat reminiscent of $P$. costata d'Orbigny, $P$. declivis Brydone and P. lehmanni Voigt \& Schneemilch; however, it is distinguishable by its peculiar, highly symmetrical colonies and the associated, marked positional polymorphism.

$P$. insolita is named for its rarity (insolitus, latin for rare).

Stratigraphic range and distribution: Early Maastrichtian (very rare in brachiopod zones 2 and 5); chalk facies in the northernmost part of the North Sea Basin.

\section{Pavolunulites danica n. sp.}

Figs $11 \mathrm{~A}-\mathrm{E}$

Holotype: MGUH 23119 (Figs 11C-E); Early Maastrichtian (brachiopod zone 2, Gedser Odde).

\section{Material: Lower Maastrichtian chalk: Denmark (Ged- ser Odde).}

Description: Colony flat and thick, fan-shaped with a ragged outline; composed of rather irregular rows of autozooids radiating from a marginal ancestrula; vibracula isolated, somewhat irregularly dispersed in the budding pattern but commonly initiating new budding rows. Ancestrula of the same size and shape as the following autozooids; followed by 2 autozooids and 1 vibraculum or by 1 autozooid and 2 vibracula. Basal wall calcitic with considerable secondary thickening, and with a rather irregular surface crossed by deep fur-

Fig. 11. Pavolunulites danica n. sp. A, basal view of complete colony (MGUH 23120; Gedser Odde). B, ancestrular region of complete, very young colony (MGUH 23121; Gjedser Odde). C, frontal view of holotype (MGUH 231 19; Gedser Odde). D, autozooids and vibraculum from the central part of the holotype $(\mathrm{C})$. E, ovicell from the distal part of the holotype (C). Scale bars $1 \mathrm{~mm}$. 


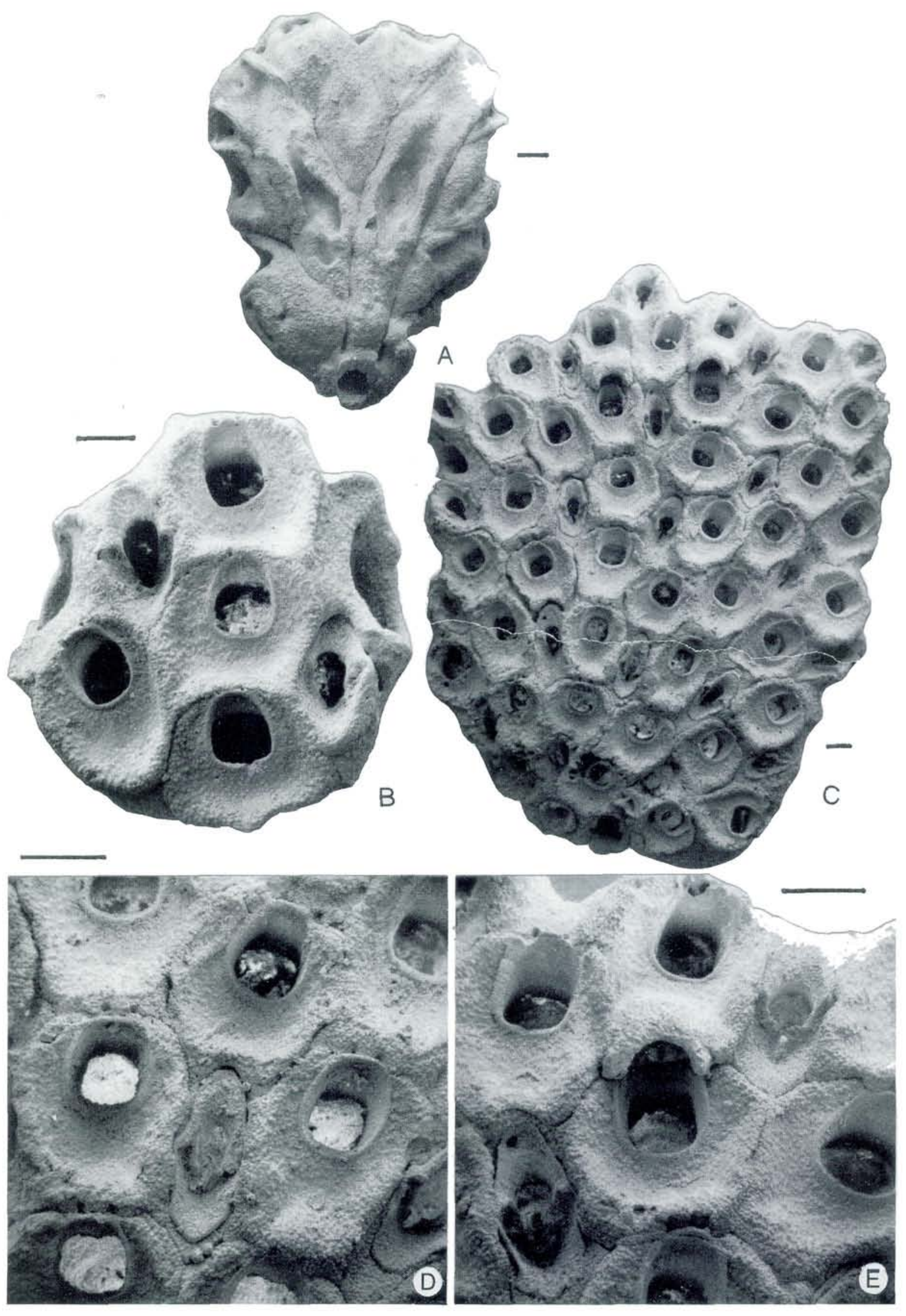

Håkansson \& Voigt: New free-living bryozoans 
rows corresponding to the lateral walls of zooidal budding rows; vibracula not visible on the basal side.

Autozooids irregularly sub-quadratic to pyriform or almost hexagonal; cryptocyst flat, bound by a prominent, thick mural rim and with an almost smooth rim around the opesia; opesiae elongate, rounded-rectangular, typically less than half the length of the zooids.

Vibracula(?) shorter than the autozooids and half as wide, with rounded distal margin; opesiae oval, with a narrow proximal slit, surrounded by a very steep, extensive cryptocyst which projects into two small spines lateral to the proximal opesiular slit; condyles broad and low.

Ovicells helmet-shaped and prominent, with a pair of proximally directed, lateral processes; situated above the associated opesia.

Remarks: The presence of a prominent ovicell is in contrast to most species assigned to the Lunulites complex; furthermore, the heterozooids of $P$. danica $\mathrm{n}$. sp. appear rather primitive in the sense that they can hardly be distinguished from the onychocellaria of many nonfree-living Cretaceous cheilostomes. Whether the heterozooids of $P$. danica, therefore, were functional vibracula or avicularia remains uncertain. In most characters $P$. danica is somewhat similar to $P$. marssoni Brydone (nom. nov. for $P$. crassa (Beissel)) and $P$. ornata (Wahle). However, it is distinguished by the lack of opesiular indentations and by its somewhat differing vibracula; from $P$. siemersi Voigt it differs in its much thicker colony, larger zooids, and the shape of its opesiae.

The name danica reflects the restricted, Danish, occurrence of this species.

Stratigraphic range and distribution: Early Maastrichtian (very rare in brachiopod zone 2); chalk facies in the northern part of the North Sea Basin.

\section{Dansk sammendrag}

Fritlevende cheilostome bryozoer udgør et af de mest karakteristiske elementer i den danske og nordtyske skrivekridtfauna, hvor deres små skiveformede til hvælvede kolonier ofte er særdeles iøjenfaldende $\mathbf{i}$ slemmeresterne. Op mod 100 arter af fritlevende bryozoer synes at vare tilstede i Skrivekridt af Maastrichtien alder,hvoraf kun godt halvdelen indtil nu er beskrevet; denne afhandling beskriver 12 hidtil ukendte arter. De tolv arter henføres til de to formslægter Lunulites og Pavolunulites, men det er allerede nu klart, at en mere gennemgribende revision af skrivekridtets fritlevende bryozo-fauna vil nødvendiggøre oprettelsen af nye slægter. Som eksempel kan nævnes artskomplekset $L$. beisseli, $L$. foveolata $\mathrm{n}$. sp. og $P$. schmidi n. sp. hvis astogeni følger et ganske karak- teristisk knopskydningsmønster selv om de p.t. må henregnes til to forskellige formslægter.

De beskrevne arter findes alle i skrivekridt af Maastrichtien alder; én art forekommer herudover i Øvre Campanien skrivekridt, og én art findes både i skrivekridt og mere kystnære kalsiltiter.

\section{Acknowledgements}

Shell International Petroleum M.B.V. (Den Haag) together with Dansk Undergrunds Consortium (Copenhagen) presented to us a well preserved specimen of Lunulites conulus n. sp. (Voigt Coll., Photocat. No. 6206) from the subsurface of the North Sea (D.U.C. well E-2x; 55 $42^{\prime} 32^{\prime \prime} \mathrm{N} / 04^{\circ} 44^{\prime} 40^{\prime \prime} \mathrm{E}$; core depth: 6683 ft.).

Jan Aaagaard and Erling Fuglsang Jensen took care of most of the photographic work, and Henrik Egelund prepared the figures, except Fig. 2, which was prepared by Dr W.K. Christensen.

\section{References}

Bassler, R.S . 1935: Bryozoa. In Quenstedt, W. (Ed.): Fossilium Catalogus. I: Animalia, 67, $229 \mathrm{pp.}$

Bassler, R. S. 1953: Bryozoa. In Moore, R. C. (Ed.): Treatise on Invertebrate Paleontology. Part G, 175 pp.

Beissel, T. 1865: Ueber die Bryozoen der Aachener Kreidebildung. Naturkundige Verhandlingen van de Hollandsche Maatschappij der Wetenschappen te Haarlem $22,92 \mathrm{pp}$.

Boardman, R., Cheetham, A. \& Cook, P. 1970: Intracolony variation and the genus concept in Bryozoa. Proceedings of the North American Paleontological Convention Part C, 294-320.

Buge, E. 1946: Catalogue des Bryozoaires types et figurés de la Collection du Laboratoire de Paléontologie du Muséum National d'Histoire Naturelle. IV, Bryozoaires cheilostomes de l'éocène du bassin de Paris figurés par $\mathrm{F}$. Canu (1907-1910). Bulletin du Muséum National d'Histoire Naturelle, $2^{\circ}$ sér. 18 (5), 428-439.

Buge, E. 1951: Bryozoaires. In: Collignon, M. (Ed.): Faune maestrichtienne de la Côte d'Ambatry (Province de Betioky), Madagascar. Ann. Géeol. Serv. Mines (Gouvernement Général de Madagascar et Dépendantes) 19 , 87-88.

Buge, E. 1955: Les Bryozoaires de Néogène de l'ouest de la France et leur signification stratigraphique et paléobiologique. Bulletin du Muséum National d'Histoire Naturelle C6, 1-436.

Cook, P. L. \& Chimonides, P. 1978: Observations on living colonies of Selenaria (Bryozoa, Cheilostomata). I. Cahiers de Biologie Marine 19, 147-158.

Cook, P. L. \& Chimonides, P. 1986: Recent and fossil Lunulitidae (Bryozoa, Cheilostomata) 6. Lunulites sensu lato and the genus Lunularia from Australia. Journal of Natural History 20, 681-705. 
Defrance, J. L. M. 1823: 'Lunulite' in Dictionaire des Sciences Naturelles 27, 359-362.

Heinberg, C. 1979: Evolutionary ecology of nine sympatric species of the pelecypod Limopsis in Cretaceous chalk. Lethaia 12, 325-340.

Heinberg, C. 1989: Bivalves from the white chalk (Maastrichtian of Denmark, IV: Nuculoidea. Bulletin of the Geological Society of Denmark 37, 227-236.

Håkansson, E. 1974: Adaptive strategies among soft bottom cheilostomes from the Danish chalk (Maastrichtian). 92 pp., Unpublished Ph.D.-thesis, University of Copenhagen.

Håkansson, E. 1975: Population structure of colonial organisms. A palaeoecological study of some free-living Cretaceous bryozoans. Documents des Laboratoires de Geologie de la Faculté des Sciences de Lyon, H. S. 3, 385-399.

Håkansson, E., Bromley, R. \& Perch-Nielsen, K., 1974: Maastrichtian chalk of north-west Europe - a pelagic shelf sediment. Special Publications of the International Association of Sedimentologists 1, 211-233.

Håkansson, E. \& Thomsen, E. 1979: Distribution and types of bryozoan communities at the boundary in Denmark. In: Birkelund, T. \& Bromley, R. (Eds): Cretaceous-Tertiary Boundary Events. I. The Maastrichtian and Danian of Denmark, 78-91.

Håkansson, E. \& Winston, J. 1985: Interstitial bryozoans: Unexpected life forms in a high energy environment. In: Nielsen, C. \& Larwood, G. (Eds): Bryozoa: Ordovician to Recent, 125-134.

Håkansson, E. \& Voigt, E. 1995: STICHOPORA - an enigmatic group of Cretaceous free-living cheilostomes. In: Gordon, D. P. \& Smith; A. M. (Eds): Abstracts. International Bryozoology Association, 10th International Conference. Wellington, New Zealand.

Johansen, M. B. 1988: Brachiopod extinctions in the Upper Cretaceous to lowermost Tertiary Chalk of Northwest Europe. Revista Espanola de Paleontologia, Numero Extraordinario, Palaeontology and Evolution: Extinction Events, 41-56.

Marsson, T. 1887: Die bryozoen der weissen schreibkreide der insel Rügen. Palæontologische Abhandlungen herausgegeben von W. Dames und E. Kayser 4/1, 112 pp. d'Orbigny, A. 1851-54: Paléontologie francaise, Terrain Crétacé 5, Bryozoaires, 1192 pp.

Schmid, F. 1982: Das erweiterte Unter-/Ober-MaastrichtGrenzprofil von Hemmoor, Niederelbe (NW-Deutschland). Geologishes Jahrbuch A 61, 7-12.

Surlyk, F 1970: Die Stratigraphie des Maastricht von Dänemark und Norddeutschland auf grund von Brachiopoden Newsletters on Stratigraphy 12, 7-16.

Surlyk, F. 1972: Morphological adaptations and population structures of the Danish Chalk brachiopods (Maastrichtian, Upper Cretaceous). Det Kongelige danske Videnskabernes Selskab 19 (2), 1-57.

Surlyk, F. 1984: The Maastrichtian Stage in NW Europe and its brachiopod zonation. Bulletin of the Geological Society of Denmark 33, 217-223.

Voigt, E. 1930: Morphologische und stratigraphische Untersuchungen über die Bryozoenfauna der oberen Kreide. I. Leopoldina 6, 379-579.

Voigt, E. 1972: Sur quelques espèces de bryozoaires cyclostomes Crétacés décrites par A. d'Orbigny. Annales de Paléontologie 63, 203-220. 